\title{
PARENTS KNOWLEDGE AND ATTITUDES TOWARDS THE USE OF ANTIBIOTICS IN PATIENTS WITHIN THE PEDIATRIC AGE RANGE
}

\author{
Ana Sofia Esteireiro ${ }^{1}$, Vânia Morais² ${ }^{2}$ Cristina Jesus Henriques ${ }^{3}$, Sara C. Ferreira ${ }^{4}$, Maria Clara Nobre ${ }^{2}$ \\ ${ }^{1}$ Serviço de Pediatria, Hospital das Caldas da Rainha, Centro Hospitalar do Oeste, Caldas da Rainha, \\ Portugal and Unidade de Saúde Familiar D. Jordão, ACES Oeste Sul, ARSLVT, Portugal. \\ 2Unidade de Saúde Familiar D. Jordão, ACES Oeste Sul, ARSLVT, Portugal. \\ ${ }^{3}$ Centro de Saúde de São Roque, ACES RAM, SESARAM, Portugal. \\ ${ }^{4}$ Unidade de Saúde Familiar Sétima Colina, ACES Lisboa Central, ARSLVT, Portugal.
}

\begin{abstract}
Aim: To assess parents' knowledge and attitudes towards the use of antibiotics within the paediatric age range.

Methods and Materials: This observational, descriptive and cross-sectional study, with a voluntary and anonymous questionnaire was implemented over three months to a sample of parents of children and teenagers enrolled on two Family Health Units, D. Jordão (rural area) and Sétima Colina (urban area).

Results: A total of 294 valid questionnaires were obtained. Only 149 (51\%) answered that antibiotics treat bacterial infections, 101 (34\%) believed that they help in the recovery of a flu and $36(12 \%)$ considered that they should always be used in case of fever. Two hundred twenty-seven (77\%), identified misuse of antimicrobials as a cause of bacterial resistance, even so, $31 \%$ became concerned if the doctor does not prescribe these drugs. Only 87 (30\%) showed high level of knowledge and a statistically significant correlation existed between higher age of parents [Odd's ratio $(O R)=2.37$ ], education $(\mathrm{OR}=3.42)$, confidence in doctors $(\mathrm{OR}=2.06)$ and level of knowledge of respondents. There was no statistically significant difference between the level of knowledge of users in the rural environment compared to those in the urban environment $(p=0.546)$.
\end{abstract}

Conclusion: Most parents are unaware of antibiotics' function, as well as the difference between viral and bacterial infections. Although they identify that misuse of these drugs may lead to bacterial resistance, parents become reluctant when antibiotics are not prescribed.

\section{ARTICLE HISTORY}

Received 20 January 2020

Accepted 8 February 2020

\author{
KEYWORDS \\ parents, antibiotics, \\ knowledge, attitudes, \\ questionnaire
}

\section{Introduction}

Antibiotics, whose function allows the prevention and cure of infections of bacterial origin, are considered one of the most relevant inventions of the $20^{\text {th }}$ century. ${ }^{1-3}$ Prior to their discovery, bacterial infections contributed significantly tzo morbidity and mortality on a global scale. ${ }^{1,4}$ Thus, antibiotics play an essential role in medical practice, ${ }^{2,5}$ so their prescription has been increasing. ${ }^{4,6}$ In 2014, these drugs contributed to $70.5 \%$ of the total anti-infectious drugs prescribed at ambulatory care and hospitals in Mainland Portugal.' However, its widespread use correlates with the development of strains of resistant bacteria. ${ }^{1,8,9}$ Although this is a natural process resulting from the selective pressure exerted by the use of antibiotics, the selection of resistant strains is

\section{CONTACT: Ana Sofia Esteireiro}

Email: esteireira@gmail.com

Address for Correspondance: Ana Sofia Esteireiro, Rua Diário de Notícias, 2500-176, Caldas da Rainha, Leiria, Portugal.

(C)2020 Pediatric Oncall enhanced by inappropriate and frequent use of this pharmacological class. ${ }^{8,10,15}$

Antibiotic resistance is an important threat to the efficacy of these drugs, leading to more expensive antibiotic alternatives with more serious side effects. ${ }^{10-12}$ This requires a greater number of consultations, complementary diagnostic tests and additional drug prescriptions, culminating in many cases in extended hospital days and, ${ }^{13,15}$ ultimately, in an increase in mortality. ${ }^{14-16}$ Antibiotic resistance is thus responsible for serious clinical consequences and represents a heavy economic investment, ${ }^{17}$ so it is currently assumed as one of the most relevant public health problems worldwide. $8,10,12,18$

Although the prescription of the antibiotic is the responsibility of the clinician, there are several factors that, directly or indirectly, may influence its decision. ${ }^{13,17,24,25}$ Parents have a distorted view of the function of these drugs, as well as of the diseases that require their use. ${ }^{13,17,24,25}$ Among the infectious conditions verified at paediatric age, most are of viral aetiology, self-limited in nature and with a very low risk of complications, and it is sufficient, in most 
cases, the use of symptomatic control. ${ }^{11,26,27}$ However, studies show that, at an early stage of the disease, the non-prescription of an antibiotic is associated with parental dissatisfaction regarding the therapeutic attitude adopted by the doctor. ${ }^{25,28}$ Data from the 2018 Eurobarometer show that Portugal is one of the European countries where there is greater ignorance about the action of this pharmacological class, as $64 \%$ of Portuguese consider that antibiotics are effective in the face of viral infection (vs. $48 \%$ of European average), $55 \%$ believe that its use contributes to the resolution of flu and colds (vs. $28 \%$ European average) and only $24 \%$ reported having received information in the last 12 months on this issue (vs. $33 \%$ of the European average)..$^{12}$

The low level of clarification in antibiotic therapy contributes to the incomplete course of treatment with these drugs, which translates into the suspension of its administration when there is improvement in symptomatology, in non-compliance with the frequency of appropriate administration, dose reduction or use of self-medication. ${ }^{11,24,25}$ Self-medication with antibiotics, in particular the sale of antibiotics without a prescription and the use of surpluses thereof, in the face of a clinical picture similar to what motivated its initial prescription, ${ }^{12,29}$ is considered one of the factors that leads to inadequate use of this pharmacological class. ${ }^{13}$ In the European panorama $7 \%$ of respondents report that they did not obtain antibiotics with a prescription, and in Portugal this value is even higher, $10 \% .{ }^{12}$ In this sense, studies have been conducted in the national territory in order to evaluate the prevalence of self-medication with antibiotics, one in the Algarve, in 2008, and another in the municipality of Vizela in $2011,{ }^{14}$ prevalence of $4 \%$ and $18.9 \%$ respectively. ${ }^{29}$

This work aims to characterize the knowledge and attitudes of parents about the use of antibiotics in paediatric age and to verify whether they differ between users of the urban vs. rural environment. It is also intended to investigate the existence of a relationship between gender, age, education, as well as between the number and age of sons, with the parent's level of knowledge about antibiotic therapy.

\section{Methods \& Materials \\ Study drawing}

An investigation protocol was elaborated, which defined the objectives and methodology of the study, with prior approval by the Ethics Committee of the Regional Health Administration of Lisbon and Tagus Valley. This was a descriptive and cross-sectional observational study with an analytical component. The data were collected through the application of a questionnaire to a convenience sample, during the period between June and August 2017.

\section{Population and sample}

The study population consisted of the parents of children and adolescents (under 18 years) enrolled in the Family Health Unit (USF) Sétima Colina and USF D. Jordão. The USF Sétima Colina is located in Lisbon (urban area) and USF D. Jordão in Lourinhã (rural area). A convenience sample was used, consisting of 294 users of the two USF over the age of 18 years, who agreed to participate in the investigation. Although it was a convenience sample, the dimension that would be needed if the sample was random was determined through the OpenEpi ${ }^{\circledR}$ system to a $95 \%$ confidence level, with the outcome number used as a reference. Written consent was obtained from the participants, after an oral and written description of the study purpose.

Inclusion criteria: parents of healthy children and adolescents (without chronic pathology that makes them more vulnerable to repeated infections).

Exclusion criteria: parents with illiteracy or inability to understand the written Portuguese language. It is also excluded all caregivers who are not parents of the children.

\section{Study instrument}

The data were obtained through the application of a questionnaire prepared by the researchers (Figure 1), not validated for the Portuguese population, based on studies with similar objectives. This is an anonymous and self-completion paper questionnaire. The questionnaire consists of 15 questions, organized into two distinct parts: part I - socio-demographic data of the respondent; part II - knowledge and attitudes about antibiotic therapy.

A pilot test was performed (total of 30 parents, 15 of each USF) in order to detect difficulties in interpreting questions or incongruities.

The final questionnaire, after rectifications, was delivered by clinical secretaries to parents who agreed to participate in the study. After completing them, the questionnaires were delivered and placed in a closed envelope designated for this purpose.

\section{Data analysis}

The data collection was carried out by the researchers and the information was introduced into a computer database (in Microsoft Excel ${ }^{\circ}$ ), created for this purpose. To ensure confidentiality, all data has been encoded with a numeric code. The variables evaluated in the study for parents were age, gender, education, nationality, number of children, the existence of preschool children, knowledge and attitudes about the use of antibiotics, their use without medical prescription, as well as the level of confidence in the attending physician. The level of knowledge about antibiotic therapy was obtained according to the number of correct answers to the 5 questions about function, use and side effects of these drugs (each correct answer corresponds to 1 point, incorrect or unfilled answers correspond to 0 points). A low level of knowledge is considered when obtained from 0 to 2 points, average knowledge between 3 and 4 points and a high level of knowledge when the respondent obtains 5 points. The level of confidence in the doctor was obtained by the answer of parents to the question "do you stay rested when the doctor does not prescribe antibiotics to your child?", considering that there is confidence when the answer is positive.

Descriptive analysis was performed, presenting frequencies and percentages for categorical variables; standard deviations for continuous variables. The questionnaires with missing values greater than $20 \%$ per questionnaire were not considered for data analysis. 
Figure 1. Questionnaire prepared by the researchers

\section{Dear user}

USF Dom Jordão intends to evaluate parents' knowledge and attitudes towards the use of antibiotics at a pediatric age. We therefore ask you to cooperate in completing this questionnaire. Your participation is anonymous and the data obtained will be used for statistical study in order to improve health care for children and adolescentes. Thank you for your collaboration.

\section{PART I-Sociodemographic data of the inquired}

1. Age years

2. Gender $\square$ Male

Female

3. Nationality

4. Schooling (choose the option concluded):

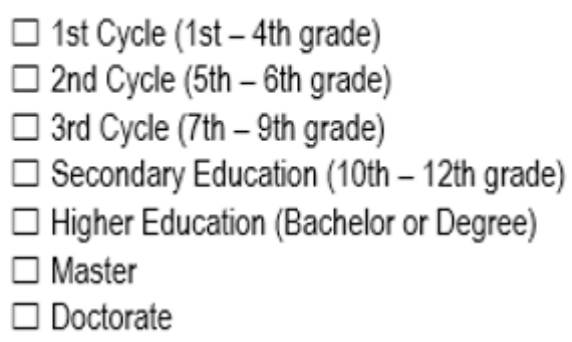

5. How many children do you have? 6. Do you have children with less than 6 years? $\square$ yes $\square$ No

\section{PART II - Knowledges and attitudes about antibiotic therapy}

\section{What is an antibiotic for?}
$\square$ Treatment of viral infections
$\square$ Treatment of bacterial infections
$\square$ Treatment of all types of infections
$\square$ They are used against parasites and fungi
$\square$ I don't know

\section{Do antibiotics help you recover faster from a flu or cold?}

$$
\square \text { yes } \square \text { No } \square \text { I don't know }
$$

9. Should antibiotics always be prescribed in case of fever?

$\square$ yes $\square$ No $\square$ Idon't know

10. Do antibiotics have side effects?

$\square$ Yes, there may be some side effects

$\square$ They don't have side effects

$\square$ I don't know

\section{Misuse of antibiotics can lead to resistant infections?}

$\square$ yes $\square$ No $\square$ Idon't know 
12. Has your child ever been treated with antibiotics? $\square$ Yes $\square$ No

12.1 If YES, have you always completed the entire treatment (number of days indicated by the doctor)?

$\square$ Yes $\square$ No

\section{2..2. If you have NOT completed the treatment, why? (choose one or more)}

$\square$ Not enough bottles were prescribed

$\square$ I thought my child was not getting better with treatment

$\square$ My child was already symptom free, so no more treatment days needed

$\square$ Emergence of allergic reaction

$\square$ Emergence of secondary symptoms

$\square$ Another motive. Which one?

13. Have you ever medicated your child with antibiotic without medical prescription? $\square$ Yes $\square$ No

13.1 If YES, where did you get the antibiotic? (choose one or more)

$\square$ In the pharmacy $\square$ I ordered through the internet

I used antibiotic that left from a previous prescription

Other. Which one?

13.2 If you answered YES, why did you medicate your child without a prescription? (choose one or more)

I couldn't make an appointment at the doctor

I was out of my residence area

My child often has the same symptoms and I already know what to do

$\square$ I gave the antibiotic on the recommendation of a friend/family member

Other. Which one?

13.3 If YES, in which of the following symptoms did you give your child antibiotics without a prescription? (choose one or more)

$\begin{array}{lll}\square \text { Throat pain } & \square \text { Urinary complaints } & \square \text { Fever } \\ \square \text { Toothache } & \square \text { Cough } & \square \text { Earache }\end{array}$

Other. Which one?

14. Where did you get your knowledge about antibiotics? (choose one or more)

Through friends and family

By family doctor

By the paediatrician

By the media (television, newspaper, etc.)

In books or magazines

$\square$ Other. Which one?

15. Do you trust when the doctor does not prescribe antibiotics to your child?

$\square$ Yes $\square$ No $\square$ Not always 
The normality of the distributions was evaluated with the Kolmogorov-Smirnov test. To test the association between variables, the Chi-Square test, and binary logistic regression were used, and the odds ratios were calculated. Statistical analysis was performed using the Software SPSS - Statistics ${ }^{\circ}$ (Statistical

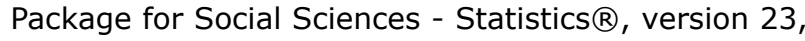
IBM inc, Chicago, IL). For all statistical tests, statistical significance was considered where the null hypothesis could be rejected for $\mathrm{p}<0.05$.

\section{Results \\ Characterization of respondents}

A total of 294 valid surveys were obtained (157 of the USF Sétima Colina and 137 of USF D. Jordão). The age of the parents ranged from 18 to 66 years with a mean age of $34.5 \pm 7.2$ years. Most respondents were female $(n=249,85 \%)$, of Portuguese nationality $(n=258,87 \%)$ and had at least the $12^{\text {th }}$ year of schooling $(n=218$, $74 \%)$. A significant number of respondents $(n=136$, $46 \%$ ) had only one child, in $84 \%$ of cases of preschool age. The socio-demographic data of the sample are summarized in Table 1.

\section{Knowledge and attitudes of respondents about antibiotic therapy}

Regarding the function of antibiotics, only 149 (51\%) of parents answered that these drugs treat bacterial infections and 104 (35\%) believed that they treat all types of infections. Total 101 (34\%) of them reported that antibiotics help to recover from a flu and $36(12 \%)$ mentioned that these drugs should always be used in case of fever. Although 239 (81\%) of respondents acknowledged that antibiotics have side effects and $227(77 \%)$ identified their inappropriate use as the source of resistant infections, 91 (31\%) reported not being rested if the doctor does not prescribe them. A significant percentage of respondents (11\%) admitted not knowing whether antibiotics have side effects and $22 \%$ are unaware of the concept of "resistant infection" or did not know whether if it can be caused by the misuse of these drugs.

Regarding antibiotic administration, a father admitted not having completed treatment, pointing out as a reason the absence of clinical improvement. Regarding self-medication, four parents (1.4\%) referred the consumption of antibiotics by their children without a prescription. In three cases, the drugs were obtained in the pharmacy without a medical prescription and, in one case, was used a remaining drug from a prior prescription. The main reason indicated by parents for self-medication was recurrence of symptoms, such as fever and cough.

The answers to the 5 questions used to assess the level of knowledge of the respondents about antibiotic therapy are found in Table 2. Only 87 (30\%) of the parents had a good level of knowledge about antibiotic therapy (Graphic 1 ). The main source of knowledge of these parents was the family doctor (55\%), followed by the media (31\%) and pediatrician (25\%). There was a statistically significant association between age, schooling, the degree of confidence in the physician and the level of knowledge of respondents $(p<0.05)$. Older parents, higher level of education and with more confidence in their attending physician presented a higher level of knowledge about antibiotic therapy (Table 3 and 4), with an Odd's ratio (OR) of 2.37 for the age variable ( $95 \%$ CI $1.31-4.29), 3.42$ for level of education ( $95 \%$ CI $1.60-7.31$ ) and 2.06 for the

Table 1. Sample sociodemographic data of parents $(n=294)$

\begin{tabular}{|c|c|c|}
\hline & & n (\%) \\
\hline \multirow[t]{3}{*}{ Gender } & Male & $38(12.9 \%)$ \\
\hline & Female & $249(84.7 \%)$ \\
\hline & Missing data & $7(2.4 \%)$ \\
\hline \multirow[t]{3}{*}{ Age (years) } & {$[18-36]$} & $148(50.3 \%)$ \\
\hline & {$[36-66]$} & $136(46.3 \%)$ \\
\hline & Missing data & $10(3.4 \%)$ \\
\hline \multirow[t]{5}{*}{ Nationality } & Portuguese & $258(87.8 \%)$ \\
\hline & Brazilian & $8(2.7 \%)$ \\
\hline & German & $3(1 \%)$ \\
\hline & Outras & $13(4.4 \%)$ \\
\hline & Missing data & $12(4.1 \%)$ \\
\hline \multirow[t]{4}{*}{ Schooling } & $\leq 9^{\text {th }}$ grade & $65(22.1 \%)$ \\
\hline & $12^{\text {th }}$ grade & $122(41.5 \%)$ \\
\hline & University education & $96(32.7 \%)$ \\
\hline & Missing data & $11(3.7 \%)$ \\
\hline \multirow[t]{3}{*}{ No. of children } & 1 & $136(46.2 \%)$ \\
\hline & 2 & $116(39.5 \%)$ \\
\hline & $\geq 3$ & $42(14.3 \%)$ \\
\hline
\end{tabular}


Table 2. Questions about function, use and side effects of antibiotics $(n=294)$

\begin{tabular}{|c|c|}
\hline & n (\%) \\
\hline \multicolumn{2}{|l|}{ What is an antibiotic for? } \\
\hline Treatment of viral infections & $20(6.8 \%)$ \\
\hline Treatment of bacterial infections & $149(50.7 \%)$ \\
\hline Treatment of all types of infections & $104(35.4 \%)$ \\
\hline They are used against parasites and fungi & $1(0.3 \%)$ \\
\hline I don't know & $9(3.1 \%)$ \\
\hline Missing data & $11(3.7 \%)$ \\
\hline \multicolumn{2}{|c|}{ Do antibiotics help you recover faster from a flu or cold? } \\
\hline Yes & $100(34 \%)$ \\
\hline No & $155(53 \%)$ \\
\hline I don't know & $33(11 \%)$ \\
\hline Missing data & $6(2 \%)$ \\
\hline \multicolumn{2}{|c|}{ Should antibiotics always be prescribed in case of fever? } \\
\hline Yes & $36(12 \%)$ \\
\hline No & $228(78 \%)$ \\
\hline I don't know & $24(8 \%)$ \\
\hline Missing data & $6(2 \%)$ \\
\hline \multicolumn{2}{|l|}{ Do antibiotics have side effects? } \\
\hline Yes, there may be some side effects & $239(81.3 \%)$ \\
\hline No have side effects & $22(7.5 \%)$ \\
\hline I don't know & $33(11.2 \%)$ \\
\hline \multicolumn{2}{|c|}{ Can misuse of antibiotics lead to resistant infections? } \\
\hline Yes & $227(77.2 \%)$ \\
\hline No & $2(0.7 \%)$ \\
\hline I don't know & $65(22.1 \%)$ \\
\hline
\end{tabular}

degree of confidence in the attending physician (95\% CI 1.18 - 3.6). There was no statistically significant difference between the level of knowledge of users in the rural environment compared to those in the urban environment $(p=0.546)$.

\section{Discussion}

The present study allowed evaluating some knowledge and attitudes of parents of these two USF regarding the use of antibiotics. The mean age of the sample was 35.4 years and $74 \%$ had at least the $12^{\text {th }}$ year. Thus, the profile of the sample corresponds to a group of young parents, with high schooling, which may be representative of the population of the units under study.

More than half $(51 \%)$ replied that antibiotics treat bacterial infections, much higher than that observed in a Portuguese study conducted in Vizela, in which only $7.9 \%$ responded correctly. ${ }^{14}$ Another study conducted in India found that only $28 \%$ of parents were aware of the correct indication of antibiotic use. ${ }^{1}$ This discrepancy could translate a lower level of education and a local reality of a predominantly rural environment. However, a Portuguese study published in 2015 obtained a higher percentage of correct answers (63.4\%). ${ }^{13}$

A relevant percentage of respondents (35\%) believe that the antibiotic is used for the treatment of all types of infections. One explanation may lie in the fact that doctors say that antibiotics serve for the eradication of microorganisms in general, rather than specifically naming bacteria. In addition, most of the population does not realize the difference between viruses and bacteria and therefore believe that antibiotics are effective for both. A similar value was found in previous studies. ${ }^{11,25}$

With regard to the usefulness of antibiotics in recovering from the flu or cold, more than a third responded affirmatively. The higher percentage was found in two Portuguese studies $(40.8 \%$ and $59.3 \%$, respectively). ${ }^{13,31}$ The difference found between the present study and that carried out in Matosinhos may be the level of poor education of the respondents in the latter, in which $53.89 \%$ had lower education.

In the study developed by Rana Farha et al., ${ }^{11}$ almost half of parents $(47.9 \%)$ agree that antibiotics should always be prescribed in case of fever. This percentage represents a considerable disparity in relation to that found in the present study (12\%).

Most respondents believe that antibiotic use has side effects $(81 \%)$. Similar results were found in previous studies. ${ }^{11,28}$ 
Graphic 1. Level of knowledge of respondents about antibiotic therapy

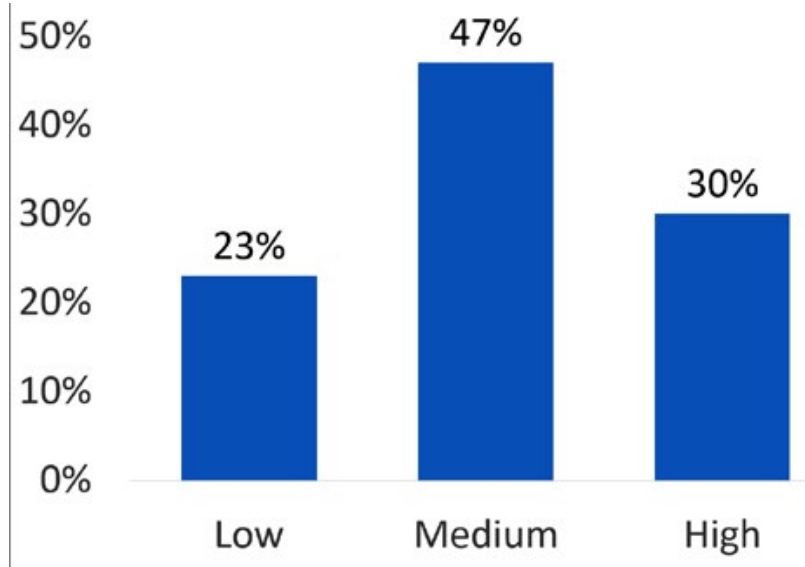

Table 3. Association between sociodemographic variables, age of children, level of confidence in the attending physician, urban living vs. rural environment and parents' level of knowledge about antibiotic therapy

\begin{tabular}{|c|c|c|c|c|c|}
\hline \multicolumn{4}{|c|}{ Level of knowledge n (\%) } & \multirow[t]{2}{*}{ Total (n) } & \multirow[t]{2}{*}{ p value } \\
\hline & Low & Medium & High & & \\
\hline \multicolumn{6}{|l|}{ Gender } \\
\hline Male & $11(3.8 \%)$ & $19(6.6 \%)$ & $8(2.8 \%)$ & 38 & \multirow{2}{*}{0.396} \\
\hline Female & $56(19.5 \%)$ & $115(40.1 \%)$ & $78(27.2 \%)$ & 249 & \\
\hline \multicolumn{6}{|l|}{ Age } \\
\hline$[18-36]$ & $43(15 \%)$ & $67(24 \%)$ & $38(13 \%)$ & 148 & \multirow{2}{*}{0.01} \\
\hline$[36-66]$ & $20(7 \%)$ & $67(24 \%)$ & $49(17 \%)$ & 136 & \\
\hline \multicolumn{6}{|l|}{ Schooling } \\
\hline$\leq 9^{\text {th }}$ grade & $24(8.5 \%)$ & $32(11.3 \%)$ & $9(3.2 \%)$ & 65 & \multirow{3}{*}{0.0001} \\
\hline $12^{\text {th }}$ grade & $27(9.5 \%)$ & $72(25.4 \%)$ & $23(8.1 \%)$ & 122 & \\
\hline $\begin{array}{l}\text { University } \\
\text { education }\end{array}$ & $14(5 \%)$ & $28(9.9 \%)$ & $54(19.1 \%)$ & 96 & \\
\hline \multicolumn{6}{|l|}{ No of children } \\
\hline 1 & $39(13.2 \%)$ & $58(19.7 \%)$ & $39(13.2 \%)$ & 136 & \multirow{3}{*}{0.324} \\
\hline$[2-3]$ & $21(7.1 \%)$ & $61(20.7 \%)$ & $34(11.5 \%)$ & 116 & \\
\hline$>3$ & $9(3.1 \%)$ & $19(6.5 \%)$ & $14(5 \%)$ & 42 & \\
\hline \multicolumn{6}{|c|}{ Preschool children } \\
\hline Yes & $53(18.3 \%)$ & $108(37.2 \%)$ & $69(23.8 \%)$ & 230 & \multirow{2}{*}{0.940} \\
\hline No & $15(5.2 \%)$ & $28(9.7 \%)$ & $17(5.8 \%)$ & 60 & \\
\hline \multicolumn{6}{|c|}{ Level of confidence in the attending physician } \\
\hline Trust & $39(13.3 \%)$ & $93(31.6 \%)$ & $71(24.1 \%)$ & 203 & \multirow{2}{*}{0.003} \\
\hline Do not trust & $30(10.2 \%)$ & $45(15.3 \%)$ & $16(5.4 \%)$ & 91 & \\
\hline \multicolumn{6}{|c|}{ Urban vs. rural } \\
\hline USF Sétima & $39(13.3 \%)$ & $69(23.5 \%)$ & $49(16.6 \%)$ & 157 & \multirow{3}{*}{0.546} \\
\hline Colina & & & & & \\
\hline USF D. Jordão & $30(21.9 \%)$ & $69(50.4 \%)$ & $38(27.7 \%)$ & 137 & \\
\hline
\end{tabular}


Table 4. Binary logistic regression to analyse the association between the independent variables and the level of knowledge of respondents about antibiotic therapy.

\begin{tabular}{|c|c|c|c|c|}
\hline Independent variables & Crude OR & $\begin{array}{c}\text { 95\% CI for } \\
\text { OR }\end{array}$ & $\begin{array}{l}\text { Adjusted } \\
\text { OR }\end{array}$ & $\begin{array}{c}\text { 95\% CI for } \\
\text { OR }\end{array}$ \\
\hline \multicolumn{5}{|l|}{ Age (years) } \\
\hline$[18-36]$ & - & - & - & - \\
\hline$[36-66]$ & 2.37 & $(1.31-4.29)$ & $2.35^{*}$ & $(1.26-4.41)$ \\
\hline \multicolumn{5}{|l|}{ Schooling } \\
\hline$\leq 9^{\text {th }}$ grade & - & - & - & - \\
\hline $12^{\text {th }}$ grade & 2.06 & $(1.06-3.98)$ & $1.923^{\#}$ & $(0.94-3.93)$ \\
\hline University education & 3.42 & $(1.60-7.31)$ & $2.57^{\#}$ & $(1.14-5.78)$ \\
\hline \multicolumn{5}{|c|}{ Level of confidence in the attending physician } \\
\hline Trust & - & - & - & - \\
\hline Do not trust & 2.06 & $(1.18-3.6)$ & $1.55^{?}$ & $(0.83-2.89)$ \\
\hline
\end{tabular}

*Adjusted OR for schooling and confidence level; \#Adjusted OR for age and confidence level; ?Adjusted OR for age and schooling.

Parents are receptive to educational messages about the proper use of antibiotics, especially when directed to adverse effects. This information can be effectively distributed by a healthcare professional in a consultation environment, thereby reducing the purchase of antibiotics without a prescription and the pressure on the doctor for their prescription. ${ }^{25}$

A significant percentage (77\%) identified its inadequate use as possible origin of resistant infections, a result higher than that observed in two Portuguese studies (67.9\% and $45.2 \%$, respectively). ${ }^{13,14}$ Only $15.5 \%$ of respondents in the study conducted in India by Agarwal et al. knew the possible resistance to infections caused by antibiotics, possibly justified by the low level of education. ${ }^{1}$

Approximately a third of respondents (31\%) do not feel secure when the doctor does not prescribe antibiotics to their child. This percentage increases to more than half $(52.4 \%)$ in the study conducted by Chinnasami et al. ${ }^{28}$ This reflects that health education alone is not enough, and it is also necessary to stimulate the change of attitude in the population. About $66 \%$ agree that doctors always have time to explain in detail the correct use of antibiotics, emphasizing the role of health professionals in increasing the level of trust on the part of parents. ${ }^{28}$

Only one parent admitted not to have completed the treatment; in southern India, the number rises to about $36 \% .{ }^{28}$ Regarding the use of antibiotics without a medical prescription, only $1.4 \%$ answered affirmatively. The highest national value was found in a study conducted in the Algarve (18.9\%), ${ }^{29}$ however, if we refer to the study carried out in Jordan, this amount ascends to $65 \% .^{11}$ The small value in the current study may mean the non-expression of the veracity of the facts for fear (although previously informed that the questionnaire would be anonymous), or on the contrary, can reflect the level of confidence that parents feel towards doctors when deciding not to prescribe antibiotics.

Only $30 \%$ of parents had a good level of knowledge about antibiotics. Analogous result (30\%) was determined by Elbru Al et al. in Saudi Arabia, ${ }^{25}$ with a very similar level of education between the two studies, since $74.1 \%$ and $75 \%$ had at least secondary education respectively.

There was a statistically significant association between age, schooling, the degree of confidence in the physician and the level of knowledge of respondents (test $X^{2}$, $\mathrm{p}<0.05$ ). Information campaigns on antibiotics should be promoted to modify the wrong conception of these drugs by individuals with lower schooling. A higher level of education may suggest greater knowledge acquired through educational training, ${ }^{11}$ since, in the study developed in India, an eighteen-fold degree of knowledge was obtained in the respondents previously submitted to training. ${ }^{28}$ It is, therefore, possible to infer that a higher level of education and the promotion of information campaigns by the mass media result in a greater degree of knowledge regarding antibiotic resistance and adverse effects.

Contrary to what was found in the study by Yao et al. ${ }^{30}$, there was no statistically significant difference between rural and urban areas in terms of knowledge (test $\left.X^{2}, p=0.546\right)$.

It should be noted that in the present study, when comparing its results with those obtained in international studies, it takes into account the socio-cultural and political differences between the populations studied since the different countries have different policies of health education and restriction of access to antibiotics.

\section{Conclusion}

This study corroborates the lack of knowledge of parents in relation to the use of this pharmacological class, demonstrated in other national and international 
studies. The health professional should be aware of the knowledge, attitudes and practices of parents using antibiotics and promote effective bidirectional communication, while assisting in the development of health education policies and strategies at the Global level.

Although parents identify that inadequate use of these drugs can lead to resistance, many remain reluctant to their non-prescription. It is therefore important to make them aware by clarifying and training on these topics, in particular about the indications of their use and the importance of complying with the prescribed treatment.

\section{Acknowledgement}

To the clinical secretaries of the USF D. Jordão and USF Sétima Colina. Their help was essential to implement this study.

Previous presentations: Work was presented in the form of a poster at the $18^{\text {th }}$ National Congress of Pediatrics and the ICCA 2018 (International Conference on Childhood and Adolescence).

Protection of people and animals: The authors stated that the procedures followed were in accordance with the regulations established by the heads of the Clinical and Ethical Investigation Committee and in accordance with the Helsinki Declaration of the World Medical Association.

Data Confidentiality: The authors claim to have followed the protocols of their work center on the publication of data.

\section{Compliance with Ethical Standards \\ Funding: None \\ Conflict of Interest: None \\ References:}

1. Agarwal S, Yewale VN, Dharmapalan D. Antibiotics use and misuse in children: a knowledge, attitude and practice survey of parents in India. J Clin Diagn Res. 2015;9:SC214.

2. Aminov RI. The role of antibiotics and antibiotic resistance in nature. Environ Microbiol. 2009;11:2970-88.

3. Archer GL, Polk RE. Treatment and prophylaxis of bacterial infections. In Kasper DL Brunwald E, Fausi AS, Hauser $\mathrm{SL}$, Longo DL, Jameson JL (eds.). Harrison's principles of internal medicine. 19th ed. New York: McGraw-Hill; 2005:789-806.

4. Van Boeckel TP, Gandra S, Ashok A, Caudron Q, Grenfell BT, Levin SA, et al. Global antibiotic consumption 2000 to 2010: an analysis of national pharmaceutical sales data. Lancet Infect Dis. 2014;14:742-50.

5. Adedeji WA. The treasure called antibiotics. Ann Postgrad Med. 2016;14:56-7.

6. Klein EY, Van Boeckel TP, Martinez EM, Pant S, Gandra $S$, Levin SA, et al. Global increase and geographic convergence in antibiotic consumption between 2000 and 2015. Proc Natl Acad Sci USA. 2018;115:E3463-70.

7. Silva A, Santos C. Análise da Utilização de Antibióticos em Portugal entre 2011 e 2014. Direção de Informação e Planeamento Estratégico. INFARMED, I.P.; 2016 [cited 201931 July]. Available from: http://www.infarmed.pt/
documents/15786/2219894/i\%C3\%B3ticos+Ambulat\%C 3\%B3rio+Hospitalar+2011-2014/.

8. Loureiro RJ, Roque F, Rodrigues AT, Herdeiro MT e Ramalheira E. O uso de antibióticos e as resistências bacterianas: breves notas sobre a sua evolução. Rev Port Saúde Pública. 2016;34:77-84.

9. Panagakou SG, Theodoridou MN, Papaevangelou V, et al. Development and assessment of a questionnaire for a descriptive cross-sectional study concerning parents' knowledge, attitudes and practises in antibiotic use in Greece. BMC Infect Dis. 2009;9:52.

10. World Health Organization. WHO Report on Surveillance of Antibiotic Consumption: 2016-2018 early implementation. Geneva: World Health Organization; 2018.

11. Farha RA, Suyagh M, Alsakran L, Alsous M, Alefishat E. Parental views of antibiotic use in children with upper respiratory tract infections in Jordan. Trop J of Pharm Res. 2016;15:2009-16.

12. European Union. Special Eurobarometer 478: Antimicrobial Resistance. November 2018. Brussels: European Commission; 2018 [cited 201931 July]. Available from: http://data.europa.eu/euodp/en/data/dataset/ S2190_90_1_478_ENG.

13. Lopes HL, Pereira JB, Carvalho MR. O que sabem os utentes sobre antibióticos: um estudo de investigação em duas Unidades de Saúde Familiar. Rev Port Med Geral Fam. 2015;31:248-54.

14. Ribeiro M, Pinto I, Pedrosa C. Comportamento da população do concelho de Vizela no consumo de antibióticos. Rev Port Saude Publica. 2009;27:57-70.

15. Direção-Geral da Saúde. Infeções e Resistências aos Antimicrobianos: Relatório Anual do Programa Prioritário 2018. Lisboa: Direção-Geral da Saúde; 2018.

16. Friedman ND, Temkin E, Carmeli Y. The negative impact of antibiotic resistance. Clin Microbiol Infect. 2016;22:41622.

17. Siddiqui S, Cheema MS, Ayub R, Shah N, Hamza A, Hussain $S$, et al. Knowledge, Attitudes and Practices of Parents Regarding Antibiotic Use in Children. J Ayub Med Coll Abbottabad 2014;26:170-3.

18. European Centre for Disease Prevention and Control. Antimicrobial resistance surveillance in Europe 2017. Annual Report of the European Antimicrobial Resistance Surveillance Network (EARS-Net). Stockholm: ECDC; 2018.

19. European Centre for Disease Prevention and Control. Antimicrobial resistance surveillance in Europe 2015. Annual Report of the European Antimicrobial Resistance Surveillance Network (EARS-Net). Stockholm: ECDC; 2017.

20. Rossignoli A, Clavenna A, Bonati M. Antibiotic prescription and prevalence rate in the outpatient paediatric population: analysis of surveys published during 2000-2005. Eur J Clin Pharmacol. 2007;63:1099-106.

21. Andrade JV, Vasconcelos P, Campos J, Camurça T. Prescrição Antibiótica no Ambulatório em Doentes Pediátricos com Patologia Respiratória. Acta Med Port. 2019;32:101-10.

22. Direcção-Geral de Saúde. Programa Nacional de Prevenção das Resistências aos Antimicrobianos. Programa Nacional de Prevenção e Controlo das Infeções Associadas aos Cuidados de Saúde. Lisboa: Direcção-Geral de Saúde; 
2009.

23. European Centre for Disease Prevention and Control. European Antimicrobial Resistance Surveillance Network (EARS-Net). Stockholm: ECDC; 2010.

24. World Health Organization. WHO global strategy for containment of antimicrobial resistance. Geneva: WHO; 2001.

25. Elbur AI, Albarraq AA, Abdallah MA. Saudi Parents' knowledge, Attitudes and Practices on Antibiotic Use for Upper Respiratory Tract Infections in Children: A population - based Survey; Taif, Kingdom of Saudi Arabia. The Journal of Medical Research 2016;2:99-103.

26. Thompson M, Vodicka TA, Blair PS, Buckley DI, Heneghan $C$, Hay AD. Duration of symptoms of respiratory tract infections in children: systematic review. BMJ. 2013;347:7027.

27. National Institute for Health and Clinical Excellence. Clinical guidelines. Prescribing of antibiotics for selflimiting respiratory tract infections in adults and children in primary care. CG69 - Issued: July 2008 [cited 201931
July]. Available from: https://www.nice.org.uk/ guidance/ cg69/evidence/full-guideline-196853293.

28. Chinnasami B, Sadasivam K, Ramraj B, Pasupathy S. Knowledge. Attitude and practice of parents towards antibiotic usage and its resistance. Int J Contemp Pediatr. 2016;3:256-61.

29. Ramalhinho I, Cordeiro C, Cavaco A, Cabrita J. Assessing determinants of self-medication with antibiotics among Portuguese people in the Algarve Region. Int J Clin Pharm. 2014;36:1039-47.

30. Yao Q, Liu C, Ferrier JA, Liu Z, Sun J. Urban-rural inequality regarding drug prescriptions in primary care facilities - a pre-post comparison of the National Essential Medicines Scheme of China. Int J Equity Health [Internet]. International Journal for Equity in Health. 2015;14:58.

31. Mateus A. Infecções respiratórias superiores: conhecimentos sobre a doença, auto-cuidados e recurso aos serviços de saúde [Upper respiratory tract infections: knowledge about the disease, self-care and use of health services]. Rev Port Clin Geral. 2003;19:415-26. Portuguese. 